\title{
Vertebral Column Deformity and Hypoxia in Salmo salar
}

\author{
Hipoxia Relacionada a Deformidad de Columna Vertebral en Salmo salar
}

"Rodrigo Castro Sánchez; " Eduardo Bustos Obregón \& **Mariana Rojas Rauco

CASTRO, S. R.; BUSTOS OBREGON, E. \& ROJAS, R. M. Vertebral column deformity and hypoxia in Salmo salar. Int. J. Morphol., 29(4):1291-1295, 2011.

SUMMARY: Vertebral Column Deformity (VCD) is a common pathology in Chilean salmon farms, lowering the quality and commercialization of the product. Hypoxia has been related to other musculoskeletal deformities, but not to VCD. This work analyzes the morphology of the vertebral column of Salmo salar alevins, cultured under hypoxic conditions (60\% O2 saturation in the water tanks) for different time periods after hatching (2, 4, 6 and 8 days). They are compared with their normoxic controls (100\% O2 saturation). Using histological (H/E), and morphometric techniques, it was found that the time of exposure to hypoxia is inversely proportional to the body length, notochordal diameter and thickness of its sheath. The organic response to hypoxia was quantified by immunohistochemistry for HIF-1a as the sensor of hypoxia. Its expression increased significantly $(\mathrm{p}<0.05)$ in the experimental groups that exhibit VCD. Although etiology for VCD is probably multifactorial, this study allows for the conclusion that hypoxia by itself, produces VCD.

KEY WORDS: Vertebral Column; Deformity; Hypoxia; Salmon.

\section{INTRODUCTION}

The controlled culture conditions in the modern salmon farm have weakened natural selection. Thus an increase in uncommon diseases has emerged (Sadler et al., 2001). One group of relevant diseases is musculoskeletal deformity that affects the quality of the final product and diminishes its commercial value (Gjerde et al., 2005), such as jaw deformities (Venegas et al., 2003), gills and opercular anomalies that are being studied in our laboratory and more recently vertebral column deformity (VCD).

VCD exhibits major deviations in the column curvature (Gavaia et al., 2001; Silverstone \& Hammell, 2002; Lewis et al., 2004; Sullivan et al., 2007) and morphological anomalies in the vertebral bodies (Witten et al., 2006; Fjelldal et al., 2007), lower weight, lower survival, faulty swimming, decreased body length and increased susceptibility to other stressors and diseases (Boglione et al., 2001., Gjerde et al.)

VCD was first reported in 1981 (McKay \& Gjerde, 1986), and associated to economic loss in the mid ' $90 \mathrm{~s}$. (Vagsholm \& Djupvik, 1998), but its etiopathogeny is not yet understood (Fjelldal et al.). Environmental (culture conditions) and genetic factors ("inbreeding") have been proposed (McKay \& Gjerde; Andrades et al., 1996; Kazlauskienë et al., 2006). For Salmo salar, high temperatures during the ova's incubation and post-hatching have been reported as causing DVC (Baeverfjord \& Wibe, 2003).

Hypoxia and HIF. VCD has not been associated to hypoxia in spite of the fact that lack of oxygen is a known teratogenic condition for the musculoskeletal system during embryonic development and the first larval stage. Hypoxia can also provoke cell apoptosis, a key process in these stages (Sanders \& Wride, 1995; Vaux \& Korsmeyer, 1999; Frank et al., 2001; Shin et al., 2004). During development in fish, sublethal hypoxia can increase the incidence of malformations by over 77.4\% (Eva et al., 2004).

A mass of water contains $1 / 30$ parts of oxygen compared to the same mass of air (Dejours, 1975; Nikinmaa \& Rees, 2005). As the temperature and salinity rise, the amount of dissolved oxygen in the water decreases. Diffusion of oxygen in water is 10,000 fold slower than in air (Priede, 2002). Therefore, the aquatic environment is very unstable in terms of oxygen concentration (Nikinmaa \& Rees).

\footnotetext{
* Escuela de Medicina Veterinaria, Universidad Iberoamericana de Ciencias y Tecnología, UNICIT, Padre Miguel de Olivares 1620, Santiago, Chile.

** Programa de Anatomía y Biología del Desarrollo, ICBM, Facultad de Medicina, Universidad de Chile, Santiago de Chile.
} 
Aquatic organisms and fish have adapted to this heterogeneity of oxygen content. The Hypoxia Inducible Factor (HIF-1) is a genetically expressed regulatory system, related to tissue response to oxygen levels below a specific critical point. Hence, detecting HIF-1 is a good predictor of tissue exposure to low oxygen concentrations.

Histogenesis and morphology of the vertebral column. The histogenesis of the vertebral body of Salmo salar starts before hatching. It is centered in the notochord and is present until adulthood (Fleming et al., 2004; Nordvik et al., 2005). Around the notochord there are several concentric layers of tissues, such as the cartilages of the neural and hemal arches, calcium deposits, collagen fibers, osteoid matrix and trabecular bone. Thus the notochord is a hydroskeleton giving functional and mechanical support to the fish. (Grotmol et al., 2006; Nordvik, 2007).

Histologically, the notochord is a cylinder organized as a concentrically stratified epithelium with chordocytes in its nucleus. Chordocytes are vacuolated cells surrounded by a monolayer of chordoblastic cells, which are arranged on the basal lamina.

At the periphery, this structure is surrounded by a thin fibrous acellular sheath, consisting of a collagenous matrix type II, covered by an elastic membrane (Parsons et al., 2002; Stemple, 2005; Grotmol et al., 2005)

After hatching (500 UTAs), Salmo salar alevins rest, digesting the lipoproteins of the yolk sac. During this period, the notochord undergoes structural modification to adapt to swimming conditions. Thus, the notochord increases its diameter and the thickness of its sheath (Grotmol et al., 2006).

This paper proposes that post-hatching hypoxia is one VCD etiological factor that slows down and alters the process of notochordal maturing, modifying the structural characteristic of the hydroskeleton and facilitating VCD of fish when they undergo natatory mechanical stress.

\section{MATERIAL AND METHOD}

Five hundred fertilized Salmo salar ova were cultured at the Center for Aquaculture of the University of Chile, in the city of Castro, Chiloe (latitude $42^{\circ} 27^{\prime} 48^{\prime \prime}$ S, longitude $73^{\circ} 48^{\prime} 29^{\prime \prime} \mathrm{W}$ ) at $9^{\circ} \mathrm{C}$ and $100 \%$ oxygen saturation (controlled by Oxiguard®). At hatching (495 UTAs) the alevins were separated into two equal groups, one in normoxia (100\% oxygen saturation) the other in hypoxia (60\% oxygen saturation). At days 2, 4, 6 and 8 after hatching, 40 fish from each group were anesthetized with $5 \%$ benzocaine (BZ-20®, Veterquímica), fixed in buffered $10 \%$ formalin and their body length was then recorded. Thereafter, samples were processed using routine histological (H/E) techniques. Five micra sections were obtained at the level of the dorsal fin. (Table I).

Morphometry. Using a photocamera (Canon A-640, 10 Megapixels) and light microscope (Axiostar Plus, Zeiss) digital images were obtained of transversal sections of alevins. The software Image Tool 3.0. [on-line] (UTHSCSA, 2002) was used to determine the notochordal diameter (the mean of two perpendicular measurements) and thickness of its sheath (mean of ten measurements at different locations).

Immunohistochemistry for HIF-1a. This was used as an oxygen sensor to determine the organism response to hypoxia. Transversal sections of alevins on xylan-coated slides were treated with the immunohistochemical method for detecting HIF-1a (polyclonal antibody H-206, Santa Cruz Biotechnology 10790) following the kit's instructions.

Statistical analysis. The results were processed with the Stata 8.0 software. Depending on the distributions of variables, the Wilcoxon test or the T test were used, with a standard error of $5 \%$.

Table I. Schematic experimental outline of collected specimens at different timing.

\begin{tabular}{cccc}
\hline Days post hatching & $\begin{array}{c}\text { UTAs at the moment of } \\
\text { collection }\end{array}$ & $\begin{array}{c}\text { Number of fish collected } \\
\text { in hypoxia }\end{array}$ & $\begin{array}{c}\text { Number of fish collected } \\
\text { in normoxia (Control) }\end{array}$ \\
\hline Day 0 & 495 & ---- & 40 \\
Day 2 & 513 & 40 & 40 \\
Day 4 & 531 & 40 & 40 \\
Day 6 & 549 & 40 & 40 \\
Day 8 & 567 & 40 & 40 \\
\hline
\end{tabular}




\section{RESULTS}

The means obtained for body lengths $(\mathrm{mm})$, notochordal diameter (um) and height of the notochordal sheath of the 2, 4, 6 and 8 day hypoxia exposed groups, clearly tended to decrease when compared with their respective normoxic controls. These differences were significant $(\mathrm{p}<0.05)$ across all parameters from day 4 onwards increasing with the longer exposure time (Table II).
HIF-1a: The immunochemical label was found in the nuclei of the spinal cord neurons (Fig. 1). The percentage of HIF-1a positive cells was directly proportional to the days of exposure to hypoxia. Labeling values (\%) for groups 2, 4, 6 and 8 days of exposure were 10,16, 23 and 35, respectively. Control normoxic groups did not show more than $2 \%$ of the label (table II). In the experimental (hypoxic) groups a scarce label was seen in the chondrocytes of the neural arches cartilages (Fig. 1).

Table II: Morphometric and immunohistochemical variables of controls (normoxic) and hypoxic alevins.

\begin{tabular}{|c|c|c|c|c|c|}
\hline & GROUP & $\begin{array}{l}\text { Body length } \\
\text { (cm) }\end{array}$ & $\begin{array}{l}\text { Notochordal } \\
\text { diameter (um) }\end{array}$ & $\begin{array}{l}\text { Thickness } \\
\text { notochordal } \\
\text { sheath (um) }\end{array}$ & $\begin{array}{c}\text { HIF immunolabe } \\
\text { cellular }(\%)\end{array}$ \\
\hline \multirow{5}{*}{$\begin{array}{l}\text { CONTROL } \\
\text { NORMOXIA }\end{array}$} & Day 0 & $18.09 \pm 0.11$ & $319 \pm 30$ & $10.45 \pm 0.1$ & 2 \\
\hline & Day 2 & $18.22 \pm 0.11$ & $325 \pm 30$ & $10.46 \pm 0.09$ & 1 \\
\hline & Day 4 & $18.35+0.10$ & $358+15$ & $10.46+0.09$ & 1 \\
\hline & Day 6 & $18.45+0.09$ & $372+14$ & $10.48+0.08$ & 2 \\
\hline & Day 8 & $18.96+0.20$ & $385+20$ & $10.51+0.09$ & 1 \\
\hline \multirow{4}{*}{ HYPOXIA } & Day 2 & $18.17 \pm 0.10$ & $322 \pm 20$ & $10.43 \pm 0.15$ & $10^{*}$ \\
\hline & Day 4 & $18.21 \pm 0.13 *$ & $340 \pm 9 *$ & $10.35 \pm 0.1 *$ & $16^{*}$ \\
\hline & Day 6 & $18.28 \pm 0.11 *$ & $354 \pm 15^{*}$ & $10.38 \pm 0.13 *$ & $23 *$ \\
\hline & Day 8 & $18.50+0.23 *$ & $362+20 *$ & $10.41+0.1 *$ & $35^{*}$ \\
\hline
\end{tabular}

*p $<0,05$ compared to control normoxia.
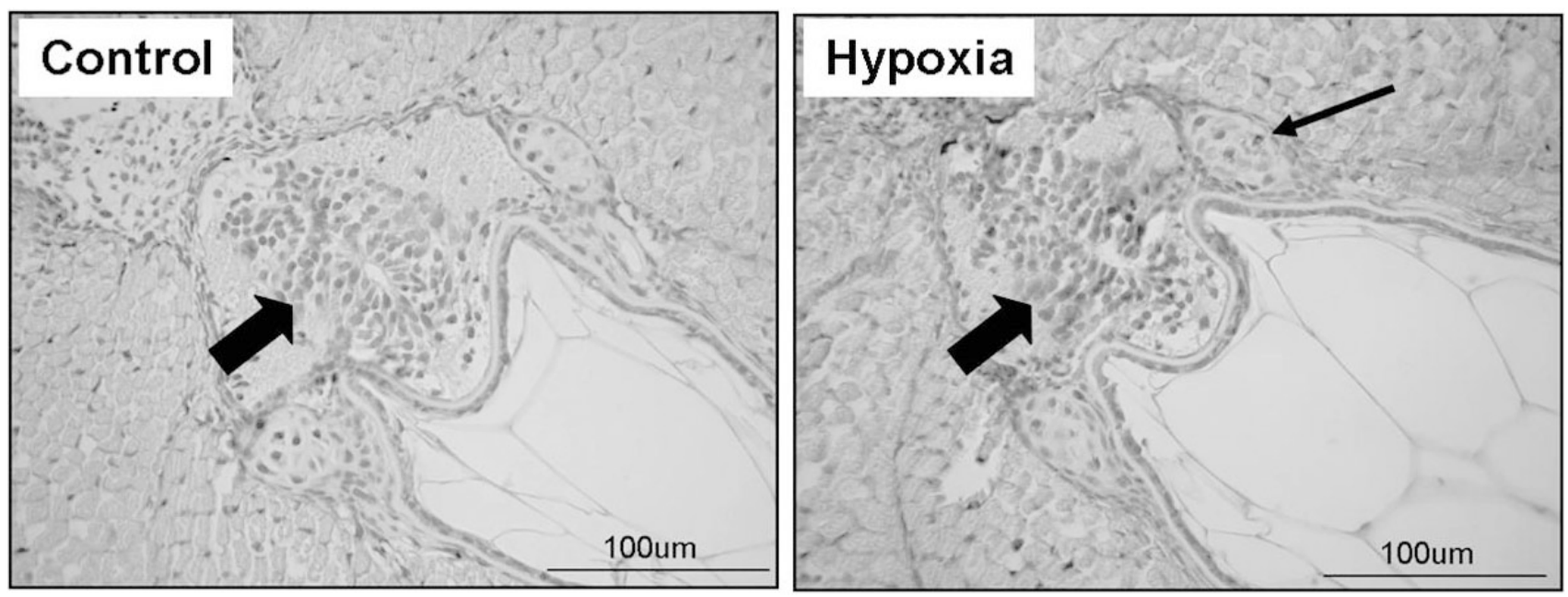

Fig. 1. Immunohistochemistry for HIF-1a in transverse sections of control and hypoxia exposed animals. Immunolabeling is seen in neuronal cells (Thick arrows) in the experimental groups versus the normoxic animals. Very scarce labeling is seen in chondrocytes of the neural arches. (Thin arrow). Notochord $(\mathrm{N})$. Barr $=100 \mathrm{um}$.

\section{DISCUSSION}

Morphological and quantitative data from the different developmental stages of the control normoxic alevins coincide with what is described in the literature for
Salmo salar (Grotmol et al., 2006) under standard salmon farming conditions in Chile.

Hypoxia and development. One adaptive mechanism in hypoxic tissues is the shifting of the metabolism to anaerobic degradation of substrates, with a lower energetic efficiency and general decrease in metabolism (Nikinmaa \& Rees). 
This situation may explain the reduction in the morphometric variables analyzed for the hypoxic individuals, though not necessarily involving the presence of VCD. However, the axial elements react to hypoxia and considering their structural importance for the natatory activity, this issue must be studied for longer developmental periods.

Hypoxia Inducible Factor (HIF-1a). Immunolabeling against HIF-1a was evident in the spinal cord neurons and very scarce in the chondrocytes of the neural and hemal arches cartilages. Absence of labeling in the osteoblasts, osteocytes, chordoblasts and chondrocytes of the vertebral column, may be due to a lower metabolic rate of these cell types at 500 UTAs, but higher before this point. At 100 - 275 UTAs elastic fibers in the notochordal sheath and vacuolization of the chordocytes occurs, providing rigidity to the notochord (Grotmol et al., 2006).

Mesenchymal condensation around the notochord from 400 UTAs onward gives rise to metameric formation of hyaline cartilages of the neural and hemal arches (Grotmol et al., 2006). They transmit muscular tensile forces to the notochord and are responsive to hypoxia as shown by their HIF-1a (+) labeling. The adaptation of these cartilaginous components to hypoxia and their performance when the animals swim may elicit VCD.

Notochordal sheath. From hatching to the first feeding period of Salmo salar, the notochord modifies its collagen disposition and mineralizes part of its sheath, thus constituting the center of the vertebral column without losing its elastic properties (Grotmol et al., 2006, Nordvik). In this way, the notochord is an axial body support, adapted to the needs of the free swimming individual. Any event that alters the notochord at this stage may produce VCD. In this way, etiopathogeny of VCD of Salmo salar associated to hypoxia is related to deformation of the vertebral column due to an alteration of the notochord.

As demonstrated in this paper, attention should be given to the elevated temperatures and high densities of ova in the cultures, and also to the control of these conditions after hatching. Therefore, it is mandatory to check the number of fish and the appropriate temperature and oxygenation levels in the water to guarantee normal fish development.

In summary, exposure to hypoxia during the first post hatching stages is associated to reduction in the morphometric parameters analyzed (body length, notochordal diameter and thickness of the notochordal sheath). Integrity of the notochord depends on avoiding hypoxia in the first stages post hatching, in order to achieve correct vertebral column morphogenesis.

ACKNOWLEDGMENTS. Special thanks to Marine Harvest S.A. for providing the fertilized eggs, to the Center for Aquaculture of the University of Chile, in the city of Castro, Chiloe for facilitating the experimental procedures and to the Laboratory for Comparative Embryology for access to their facilities which supported this work.

CASTRO, S. R.; BUSTOS OBREGON, E. \& ROJAS, R. M. Hipoxia relacionada a deformidad de columna vertebral en Salmo salar. Int. J. Morphol., 29(4):1291-1295, 2011.

RESUMEN: La deformidad de columna vertebral (DCV) es una patología que se presenta frecuentemente en la salmonicultura chilena, disminuyendo la calidad y comercialización del producto. La hipoxia ha sido relacionada a otras deformidades musculoesqueléticas pero no a DCV. Este trabajo analiza la morfología de la columna vertebral en alevines Salmo salar cultivados en condiciones de hipoxia ( $60 \%$ de saturación de $\mathrm{O}_{2}$ ) en diferentes momentos después de la eclosión (2, 4, 6 y 8 días) y son comparados con sus respectivos controles en normóxia (100\% de saturación de $\mathrm{O}_{2}$ ). Utilizando técnica histológica (H/E) y morfométrica, se determinó que el tiempo de exposición a hipoxia es inversamente proporcional a la longitud corporal, diámetro notocordal y grosor de su vaina. La respuesta orgánica a hipoxia fue cuantificada mediante inmunohistoquímica contra HIF-1a como censor de hipoxia. Su expresión incrementó significativamente $(\mathrm{p}<0,05)$ en los grupos experimentales que presentaron DCV. Aunque la etiología de DCV es probablemente multifactorial, este estudio permite concluir que la exposición a hipoxia puede provocar DCV por sí sola.

PALABRAS CLAVE: Columna vertebral; Deformidad; Hipoxia; Salmón.

\section{REFERENCES}

Andrades, J.; Becerra, J. \& Fernandez, P. Skeletal deformities in larval juvenile and adult stages of cultured gilthead sea bream Sparus aurata L. Aquaculture, 141:1-11, 1996.

Baeverfjord, G. \& Wibe, A. Short tail deformities in Atlantic salmoneffect of freshwater production temperature. Beyond monoculture, E. A. S. Special Publication, 27:3-4, 2003.

Boglione, C.; Gagliardi, G.; Scardi, M. \& Cataudella, S. Skeletal descriptors and quality assessment in larvae and post-larvae of wild-caught and hatchery-reared gilthead sea bream (Sparus aurata L. 1758). Aquaculture, 192:1-22, 2001.

Dejours, P. Principles of comparative respiratory physiology. Amsterdam, Elsevier-North-Holland Biomedical Press, 1975. p. 253.

Eva, H.; Shang, H. \& Rudolf, S. Aquatic hypoxia is a teratogen and affects fish embryonic development. Environ. Sci. Technol., 38:4763-7, 2004.

Fjelldal, P.; Hansen, T. \& Berg, A. A radiological study on the development of vertebral deformities in cultured Atlantic salmon (Salmo salar L.). Aquaculture, 273:721-8. 2007. 
Fleming, A.; Keynes, R.; Tannahill, D. A central role for the notochord in vertebral patterning. Development 131:873-80, 2004.

Frank, J.; Uli, W.; Roger, A.; Christian, I. \& Stefanie, D. Chronic Hypoxia Induces Apoptosis in Cardiac Myocytes: A Possible Role for Bcl-2-like Proteins. Biochem. Biophys. Res. Comun., 286:419-25, 2001.

Gavaia, P.; Dinis, M. \& Cancela, M. Osteological development and abnormalities of the vertebral column and caudal skeleton in larval and juvenile stages of hatchery-reared Senegale sole (Solea senegalensis). Aquaculture, 211:305-23, 2001.

Gjerde, B.; Pante, M. \& Baeverfjord, G. Genetic variation for a vertebral deformity in Atlantic salmon (Salmo salar). Aquaculture, 244:77-87, 2005.

Grotmol, S.; Nordvik, K.; Kryvi, H. \& Totland, G. A segmental pattern of alkaline phosphatase activity within the notochord coincides with the initial formation of the vertebral bodies. $J$. Anat., 206:427-36, 2005.

Grotmol, S.; Kryvi, H.; Keynes, R.; Krossoy, C.; Nordvik, K. \& Totland, G. Stepwise enforcement of the notochord and its intersection with the myoseptum: an evolutionary path leading to development of the vertebra?. J. Anat., 209:339-57, 2006.

Kazlauskienë, N.; Leliûna, E. \& Kesminas, V. Peculiarities of opercular malformations of salmon (Salmo salar 1.) juveniles reared in the Zeimena salmon hatchery. Acta Zoologica Lituanica, 16:312-16, 2006.

Lewis, L.; Lall, S. \& Witten, P. Morphological descriptions of the early stages of spine and vertebral development in hatcheryreared larval and juvenile Atlantic halibut (Hippoglossus hippoglossus). Aquaculture, 241:47-59, 2004.

Mckay, L. \& Gjerde, B. Genetic variation for a spinal deformity in Atlantic salmon. Aquaculture, 52:263-72, 1986.

Nikinmaa, M. \& Rees, B. Oxygen-dependent gene expression in fishes. Am. J. Physiol. Regul. Integr. Comp. Physiol., 288:107990, 2005.

Nordvik, K.; Kryvi, H.; Totland, G. \& Grotmol, S. The salmon vertebral body develops through mineralization of two preformed tissues that are encompassed by two layers of bone. J. Anat., 206:103-44, 2005.

Nordvik, K. From notochord to vertebral column: studies on Atlantic salmon (Salmo salar L.). Dissertation for the degree philosophiae doctor $(\mathrm{PhD})$ at the University of Bergen, Norway, 2007.

Parsons, M.; Pollard, S.; Saude, L.; Feldman, B.; Coutinho Hirst, E. \& Stemple, D. Zebrafish mutants identify an essential role for laminins in notochord formation. Development, 129:313746, 2002
Priede, M. Biology of salmon In: Stead, S.; Laird, L. (eds.) Handbook of Salmon Farming. U. K., Springer-Praxis, 2002. pp.1-35.

Sadler, J.; Pankhurst, P. \& King, H. High prevalence of skeletal deformity and reduced gill surface area in triploid Atlantic salmon (Salmo salar L.) Aquaculture, 198:369-86, 2001.

Sanders, E. \& Wride, M. Programmed Cell Death in Development. Int. Rev. Cytol., 163:105-73, 1995.

Shin, D.; Lee, E.; Kim, J.; Kwon, B.; Jung, M.; Jee, Y.; Kim, J.; Bae, S. \& Chang, Y. Protective effect of growth hormone on neuronal apoptosis after hypoxia-ischemia in the neonatal rat brain. Neurosci. Lett., 354:64-8, 2004.

Silverstone, A. \& Hammell, L. Spinal deformities in farmed Atlantic salmon. Can. Vet. J., 43:782-4, 2002.

Stemple, D. Structure and function of the notochord: an essential organ for chordate development. Development, 132:2503-12, 2005 .

Sullivan, M.; Hammond, G.; Roberts, R. \& Manchester, N. Spinal deformation in commercially cultured Atlantic salmon, Salmo salar L.: a clinical and radiological study. J. Fish Dis., 30:745$52,2007$.

UTHSCSA. Software Image Tool 3.0. Department of Dental Diagnostic Science at The University of Texas Health Science Center, San Antonio, Texas [on line]. <http://ddsdx.uthscsa.edu/ dig/itdesc.html>. [searched:28/05/2010]. 2002.

Vagsholm, I. \& Djupvik, H. Risk factors for spinal deformities in Atlantic salmon (Salmo salar L.). J. Fish Dis. 21:47-53, 1998.

Vaux, D. \& Korsmeyer, S. Cell death in development review. Cell, 96:245-54, 1999.

Venegas, F.; Montiel, E.; Forno, P. \& Rojas, M. Histology of the Jaw deformation in salmon of Southern Chile (Salmo salar). Int. J. Morphol., 21:211-19, 2003.

Witten, P.; Obach, A.; Huysseune, A. \& Baeverfjord, G. Vertebrae fusion in Atlantic salmon (Salmo salar): Development, aggravation and pathways of containment. Aquaculture, 258:16472, 2006.

\section{Correspondence to:}

Rodrigo Castro Sánchez,

Pasaje San Oscar 2810

Código Postal 9275978

Maipú, Santiago

CHILE.

\section{E-mail: rocavet@gmail.com}

Received: 15-07-2011 Accepted: 27-09-2011 